Original Research Paper

\title{
Thermodynamics, Non-Linear Isotherms, Statistical Modeling and Optimization of Phosphorus Adsorption from Wastewater
}

\author{
Akinpelu Kamoru Babayemi \\ Department of Chemical Engineering, Anambra State University, Nigeria
}

Article history

Received: 11-11-2016

Revised: $15-11-2016$

Accepted: 19-11-2016

Email: akinbabs40yahoo.com

\begin{abstract}
Palm Kernel Shell (PKN), an eco-friendly biomass, was carbonized and activated for the removal of phosphorus from wastewater through batch adsorption process. The studies evaluate the effects of $\mathrm{pH}$, particle size, dosage and contact time on the adsorption capacity of the prepared adsorbent. The equilibrium concentration data and the amount of adsorption were described using non-linear regression analysis of the curve fitting toolbox of MATLAB 7.0. The mechanism of adsorption was determined through thermodynamic properties such as change in free energy $\Delta \mathrm{G}\left(\mathrm{KJ} \mathrm{mol}^{-1}\right)$ and change in entropy $\Delta \mathrm{S}\left(\mathrm{Jmol}^{-1} \mathrm{~K}^{-1}\right)$. Statistical modeling via Central Composite Design (CCD) for process optimization was carried out. The obtained results showed that, adsorption data conformed to Freundlick Isotherm. The positive values of $\Delta \mathrm{H}\left(\mathrm{KJ} \mathrm{mol}^{-1}\right)$ and $\Delta \mathrm{S}\left(\mathrm{J} \mathrm{mol}^{-1} \mathrm{~K}^{-1}\right)$ indicate the endothermic character of the reaction and the increased randomness at the solid-solution interface respectively during the adsorption process. The most significant main effect for performance of the adsorbent is contact time $\left(\mathrm{P}_{\text {value }}=0.0000\right)$. Based on the result of the optimization of response surface model fit to experimental data, PKN reduced the effluent concentration from 373 to $24.095 \mathrm{mg} \mathrm{L}^{-1}$, a performance of $93.54 \%$. The minimum $\mathrm{pH} 2$, dosage $(1000 \mathrm{mg})$ and particle size $(0.2 \mathrm{~mm})$ are local while the contact time $(4.1 \mathrm{~h})$ is a global optimum.
\end{abstract}

Keywords: Phosphorus, Palm Kernel Shell, Adsorbent, Activated Carbon, Isotherms

\section{Introduction}

Industrialization is inevitable, various devastating ecological and human disasters, which have continuously occurred over the last three decades or so implicate industries as major contributors to environmental degradation and pollution problems of various magnitudes. Rapid industrial developments in developed and developing countries have increased hazardous wastes generation several fold (Fridriskhberg, 1984). Low level of environmental awareness in most of the developing countries has prompted indiscriminate discharges of those wastes into water bodies.

Phosphorus pollution is a major problem resulting from this improper disposal of phosphorus containing industrial wastes generated especially from indigenous chemical industries into surface waters (Akpor et al., 2013; Surche, 2011). The excess content of phosphorus in receiving waters leads to extensive algae growth, coloured, murky, odourous and unwholesome surface waters, fish kills and loss of many other aquatic animals (Babayemi, 2014). Failure to halt further deterioration of environmental quality might have adverse effects on the large segment of the population with serious political and socio-economic implications.

Against this background, a batch adsorption process has been adopted using palm kernel shells as adsorbents. Although, some conventional methods involving the use of synthetic organic and inorganic chemicals have been used, yet the health and environmental concerns associated with such methods have made them inefficient. 
Furthermore, producing activated carbons from palm kernel shells, an agricultural waste, for this purpose will definitely reduce the cost of importing the activated carbon into the country as well as providing an alternative means of waste reduction and reuse.

Adsorption is a process that occurs when a gas or liquid solute accumulates on the surface of a solid or liquid, forming a film of molecules or atoms (Sincero and Sincero, 2004; Metcalf and Eddy, 2003). The substance attached to the surface is called adsorbate and the substance to which it is attached is known as the adsorbent (Bansal and Goyal, 2005). The term sorption is used to describe every type of capture of a substance from the external surface of solids, liquids or mesomorphs as well as from the internal surface of porous solids or liquids.

Activated carbons are amorphous solid adsorbents that can be produced from almost all carbon-rich materials, including wood, fruit stones, peat, lignite, shells and other raw materials (Roque-Malherbe, 2007). Their unique adsorption properties result from their high surface areas, adequate pore size distributions, broad range of surface functional groups and relatively high mechanical strength. They are one of the most widely used adsorbents in the area of separation, storage and purification of gases and liquids, due to the high affinity and capacity displayed toward many substances (Reynolds and Richards, 1996; Uwadiae et al., 2010).
Consequently, activated carbons are used extensively for the removal of undesirable odour, colour, taste and other organic and inorganic impurities from domestic and industrial wastewater.

\section{Materials and Methods}

Palm kernel shells were obtained from Umuoma village, near Anambra State University Campus, Uli. The shells were cleaned and dried in an oven at $110^{\circ} \mathrm{C}$ for $24 \mathrm{~h}$. The dried material was weighed and then introduced into the hot zone of the muffle furnace for carbonization. The temperature of the muffle furnace was increased by $10^{\circ} \mathrm{C}$ per minute from $200^{\circ} \mathrm{C}$ to $800^{\circ} \mathrm{C}$ and kept constant for $2 \mathrm{~h}$ for charring. The charred material was removed from the furnace and allowed to cool to room temperature. The carbonized material was ground and sieved into $0.2,0.4,0.6,0.8$ and $1.0 \mathrm{~mm}$ particle sizes respectively. The various fractions were impregnated with $1 \mathrm{M} \quad \mathrm{H}_{2} \mathrm{SO}_{4}$ in separate beakers for $12 \mathrm{~h}$ after which they were washed with de-ionized water until pH6.8-pH7, filtered and dried in an oven at $110^{\circ} \mathrm{C}$ for $24 \mathrm{~h}$ before being packed in an air tight sample bags for use (Babayemi, 2014).

The effluent used in this study was collected from Federal Superphosphate fertilizer company, Kaduna, Nigeria. The effluent was characterized and the result of characterization is presented in Table 1.

Table 1. Characterization result of waste water effluent before and after adsorption

\begin{tabular}{llll}
\hline Parameters & $\mathrm{S} . \mathrm{I}$ & Before adsorption & After adsorption \\
\hline Colour & Hazen & 250 & - \\
PH & - & 8.00 & 10.00 \\
Conductivity & $\mu / \mathrm{cm}^{3}$ & $1.88 \times 10^{4}$ & $0.21 \times 10^{4}$ \\
Turbidity & $\mathrm{NTU}$ & 872.00 & 2.00 \\
Total Solid & $\mathrm{mg} / 1$ & 6530 & 31.4 \\
Acidity & $\mathrm{mg} / 1$ & 30 & 10.00 \\
Alkalinity & $\mathrm{mg} / 1$ & 485 & 500.00 \\
Manganese & $\mathrm{mg} / 1$ & 410.70 & - \\
Potassium & $\mathrm{mg} / 1$ & 420 & - \\
Chloride & $\mathrm{mg} / 1$ & 996.43 & 98.00 \\
COD & $\mathrm{mg} / 1$ & 289.77 & 5.00 \\
Dissolved Oxygen & $\mathrm{mg} / 1$ & 28.52 & 68.00 \\
BOD & $\mathrm{mg} / 1$ & 318.29 & - \\
Sulphate & $\mathrm{mg} / 1$ & 185 & 1.20 \\
Nitrate & $\mathrm{mg} / 1$ & 0.10 & - \\
Copper & $\mathrm{mg} / 1$ & 12 & - \\
Phosphate & $\mathrm{mg} / 1$ & 373.04 & 21.00 \\
Total Hardness & $\mathrm{mg} / 1$ & 80 & 10.00 \\
Lead & $\mathrm{mg} / 1$ & 0.9 & - \\
Magnesium & $\mathrm{mg} / 1$ & 19.46 & - \\
Iron & $\mathrm{mg} / 1$ & 2.75 & - \\
\hline & & & \\
\hline
\end{tabular}




\section{Batch Adsorption Experiment}

The adsorption experiment was carried out by batch methods. The $\mathrm{pH}$ level of the effluent was measured with the aid of a digital $\mathrm{pH}$ meter. About $100 \mathrm{~mL}$ of the effluent was measured into a conical flask and the $\mathrm{pH}$ adjusted to $\mathrm{pH} 2.1 .0 \mathrm{~g}$ of $0.2 \mathrm{~mm}$ particle size PKN was added to the effluent in the conical flask containing the effluent and placed on a magnetic stirrer.

The stirring was done at 30,60, 120, 180, 240 and $300 \mathrm{~min}$ respectively. Upon the completion of each stirring period, the solution was filtered and the residual concentration of the filterate was determined using UV-Spectrophotometer set at wavelength of 650 $\mathrm{nm}$ (Babayemi, 2014). The same procedure was repeated for the remaining quantities of adsorbents, particle sizes and $\mathrm{pH}$.

\section{Experimental Plan of the CCD Model}

Statistical Central Composite Design with a $2^{3}$ full factorial design is employed (Babayemi, 2015). The standard CCD is constructed from a $2^{m-4}$ designs for the cube portion, which is augmented with centre points and star points. Number of experimental points $(N)$ for CCD is:

$$
N=2^{m-t}+2 m+N_{o}
$$

Where:

$m=$ The number of variables $\left(m=4: x_{1}, x_{2} x_{3} x_{4}\right)$

$t=$ The degree of fractionality $(t=0$, since $\mathrm{m}$ is not greater than 4)

$N_{o} \quad=$ The centre point $\left(N_{o}\right.$ is chosen to be 3$)$

$x_{1}, x_{2} x_{3} x_{4}=$ The independent variables representing $\mathrm{pH}$, dosage, particle size and contact time respectively

\section{Results and Discussion}

\section{Thermodynamics Studies}

The mechanism of adsorption was determined through thermodynamic properties such as change in free energy $\Delta G$ and change in entropy $\Delta S$. The thermodynamic equilibrium constant $\mathrm{K}_{\mathrm{L}}$ for the sorption was determined from the intercepts of the plots $C_{e} / q_{e}$ versus $C_{e}$ as presented in Fig. 1. $\Delta G, \Delta H$ and $\Delta S$ are calculated from Van't Hoff Equation (Fridriskhberg, 1984; Babayemi, 2015; Nwabanne, 2010; Menkiti, 2010):

$\Delta G=-R T \operatorname{LnK}_{L}$

$L n K_{L}=\Delta S / R-\Delta H / R T$

$L n K_{L 1} / K_{L 2}=-\Delta H / R\left(1 / T_{2}-1 / T_{1}\right)$

The calculated thermodynamic parameters are presented in Table 2. $\Delta H>0$ indicates the endothermic character of the reaction and $\Delta S>0$ is an indication of the increased randomness at the solid-solution interface during the adsorption process. Also, the $\Delta G>0$ and $K_{L}<1$ show that, the adsorption of phosphorus on PKN under the chosen experimental conditions was not spontaneous (Fridriskhberg, 1984; Metcalf and Eddy, 2003; Nwabanne, 2010; Gueu et al., 2006).

\section{Non-Linear Isotherm Model}

The non-linear isotherm models for Langmuir, Freundlick and Temkin are expressed as follows (Fridriskhberg, 1984).

Langmuir Isotherm:

$Q_{e}=K C_{e} / 1+K C_{e}$

Freunlick Isotherm:

$Q_{e}=K C^{n}{ }_{e}$

Temkin Isotherm:

$Q_{e}=(R T / b) \operatorname{Ln}\left(K_{t} C_{e}\right)$

The adsorption data were analyzed and the Isotherms constants determined through the non-linear regression analysis of the curve fitting toolbox of MATLAB 7.0. The numerical fit results are shown in Table 3 and graphically presented in Fig. 2.

Table 2. Thermodynamic parameters for the adsorption of phosphorus on PKN

\begin{tabular}{llllll}
\hline Adsorbents & Temperature $(\mathrm{K})$ & $\mathrm{K}_{\mathrm{L}}$ & $\Delta \mathrm{G}\left(\mathrm{KJmol}^{-1}\right)$ & $\Delta \mathrm{S}\left(\mathrm{Jmol}^{-1} \mathrm{~K}^{-1}\right)$ & $\Delta \mathrm{H}\left(\mathrm{KJmol}{ }^{-1}\right)$ \\
\hline PKN & 303 & 0.0196 & 9.90 & - & - \\
& 308 & 0.0120 & 11.32 & 588.21 & 192.49 \\
& 313 & 0.0166 & 10.66 & - & - \\
\hline
\end{tabular}

Table 3. Numerical fit result for non-linear isotherm

\begin{tabular}{lllllllll}
\hline Isotherm & $\mathrm{K}$ & $\mathrm{R}$ & $\mathrm{b}$ & $\mathrm{K}_{\mathrm{t}}$ & $\mathrm{R}^{2}$ & $\mathrm{Adj}^{2} \mathrm{R}^{2}$ & $\mathrm{SSE}$ & $\mathrm{RMSE}$ \\
\hline Freundlick & $4.454 \mathrm{e}^{-6}$ & - & - & - & 0.9786 & 0.9715 & 0.02365 & 0.08789 \\
Langmuir & 0.08249 & - & - & - & 01158 & 0.1158 & 0.97940 & 0.49480 \\
Temkin & - & 3.385 & 2.833 & 0.03906 & 0.9376 & 0.9168 & 0.09180 & 0.15180 \\
\hline
\end{tabular}


Table 4. Coefficients of process model for batch adsorption of PKN

\begin{tabular}{llllll}
\hline Variable & Coefficient & Reg. Coefficient of variable & $\mathrm{P}_{\text {values }}$ & $\mathrm{R}^{2}$ & $\mathrm{Adj}^{2}$ \\
\hline Constant & 105.6181 & - & - & 0.9902 & 0.9788 \\
$\mathrm{x}_{1}$ & -0.6633 & 0.1484 & 0.0655 & - & - \\
$\mathrm{x}_{2}$ & -0.0502 & 0.1768 & 0.0368 & - & - \\
$\mathrm{x}_{3}$ & 24.2995 & 0.1653 & 0.0467 & - & - \\
$\mathrm{x}_{4}$ & -28.3824 & 0.4439 & 0.0000 & - & - \\
$\mathrm{x}_{1} \mathrm{x}_{2}$ & 0.0007 & 0.0028 & 0.4885 & - & - \\
$\mathrm{x}_{1} \mathrm{x}_{3}$ & -0.2453 & 0.2504 & 0.0062 & - & - \\
$\mathrm{x}_{1} \mathrm{x}_{4}$ & 0.0387 & 0.0169 & 0.4310 & - & - \\
$\mathrm{X}_{2} \mathrm{x}_{3}$ & -0.102 & 0.0039 & 0.4840 & - & - \\
$\mathrm{X}_{2} \mathrm{x}_{4}$ & -0.0002 & 0.5165 & 0.0000 & - & - \\
$\mathrm{X}_{3} \mathrm{x}_{4}$ & -1.0246 & 0.0348 & 0.3602 & - & - \\
$\mathrm{x}^{2}{ }_{1}$ & 0.1874 & 0.1508 & 0.0625 & - & - \\
$\mathrm{x}_{2}{ }^{2}$ & 0.00024 & 0.1682 & 0.0440 & - & - \\
$\mathrm{x}_{3}$ & 7.3862 & 0.1843 & 0.0311 & - & - \\
$\mathrm{x}_{4}{ }$ & 3.4835 & 0.3818 & 0.0001 & - & - \\
\hline
\end{tabular}

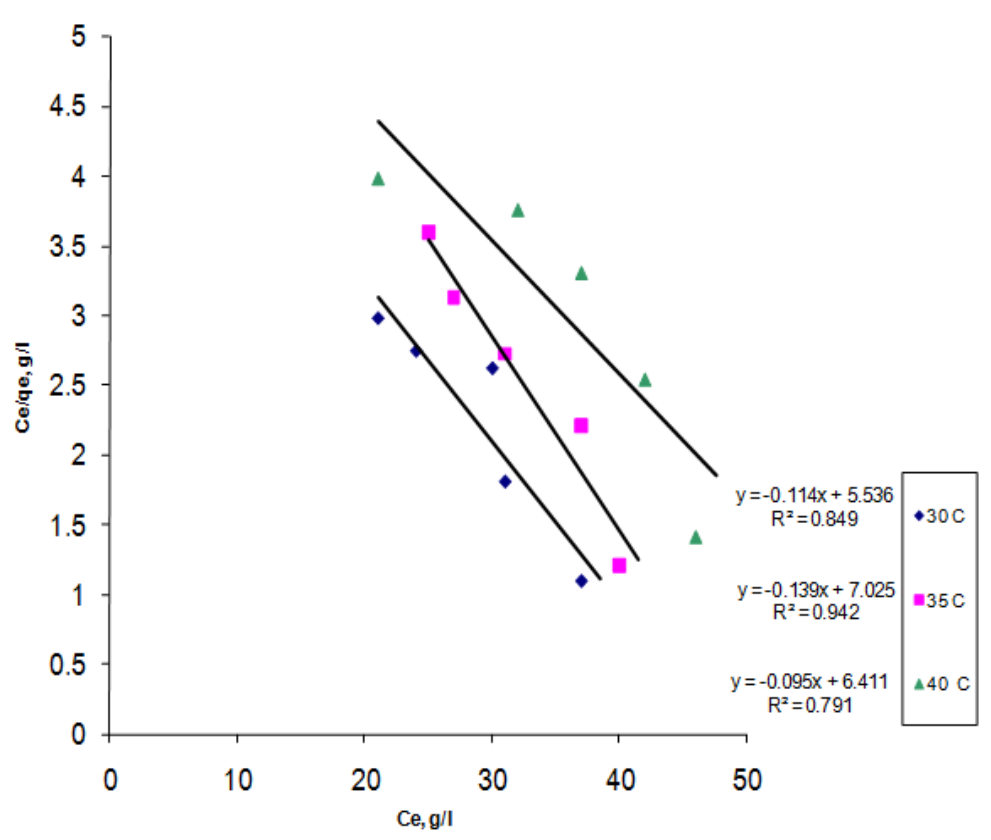

Fig. 1. Langmuir isotherm for the adsorption of phosphorus on PKN

\section{Statistical Modeling and Optimization}

The adsorption process was modeled using the general equation:

$$
\begin{aligned}
& Y=b_{o}+b_{1} x_{1}+b_{2} x_{2}+b_{3} x_{3}+b_{4} x_{4}+b_{5} x_{1} x_{2} \\
& +b_{6} x_{1} x_{3}+b_{7} x_{1} x_{4}+b_{8} x_{2} x_{3}+b_{9} x_{2} x_{4}+b_{10} x_{3} x_{4} \\
& +b_{11} x_{1}^{2}+b_{12} X_{2}^{2}+b_{13} x_{3}^{2}+b_{14} x_{4}^{2}
\end{aligned}
$$

where, $Y$ is the dependent variable representing the amount of phosphorus adsorbed per gram of the adsorbent.

$x_{1}, x_{2}, x_{3}, x_{4}$ are the independent variables representing $\mathrm{pH}$, dosage, particle size and contact time respectively. Based on the observation in Table 4, the interactions $x_{1} x_{2}, x_{1} x_{4}, x_{2} x_{3}$ and $x_{3} x_{4}$ may be deleted from the model without any major impact on the model accuracy, thus we have:

$$
\begin{aligned}
& Y=b_{o}+b_{1} x_{1}+b_{2} x_{2}+b_{3} x_{3}+b_{4} x_{4}+b_{6} x_{1} x_{3} \\
& +b_{9} x_{2} x_{4}+b_{11} x_{1}{ }^{2}+b_{12} x_{2}{ }^{2}+b_{13} x^{2}{ }_{3}+b_{14} x_{4}{ }^{2}
\end{aligned}
$$

The $\mathrm{R}^{2}$ and the adjusted $\mathrm{R}^{2}$ values reveal that, the model predicts the data to $93.54 \%$. The main attribute to effective performance of PKN as adsorbent is its contact time. This agrees with the surface plots that show linear profile in phosphorus concentration with $\mathrm{pH}$, dosage and particle size but a quadratic profile with time as presented in Fig. 3-8. The model accuracy is validated by the values of $R^{2}(0.9902)$ and $\operatorname{Adj} . R^{2}(0.9788)$ and the closeness of the predicted values to the experimental values as presented in Fig. 9. 


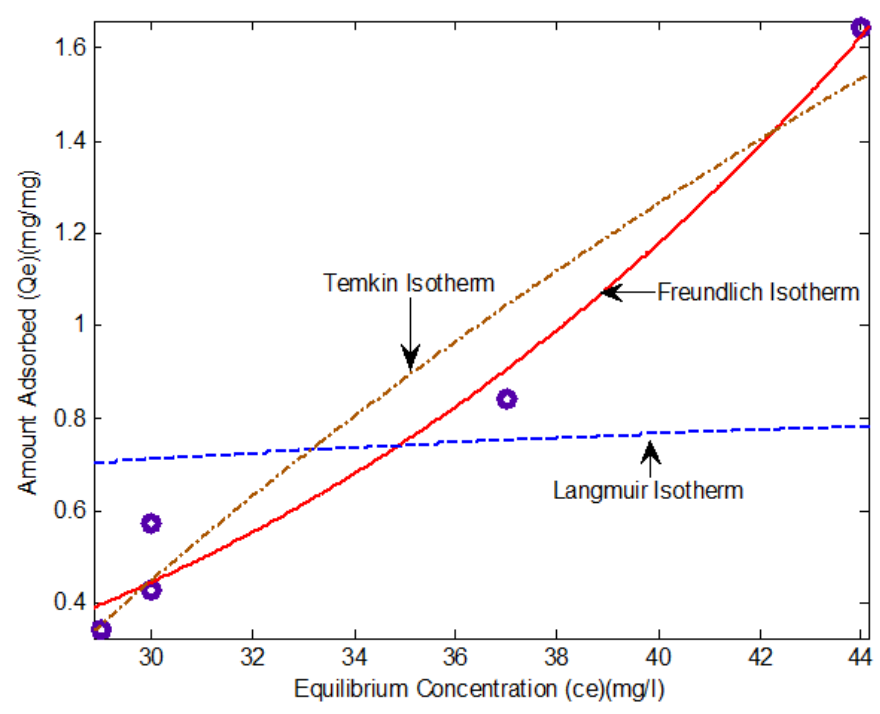

Fig. 2. Isotherm plot for fit to $\mathrm{PKN}$ activated with $\mathrm{H}_{2} \mathrm{SO}_{4}$

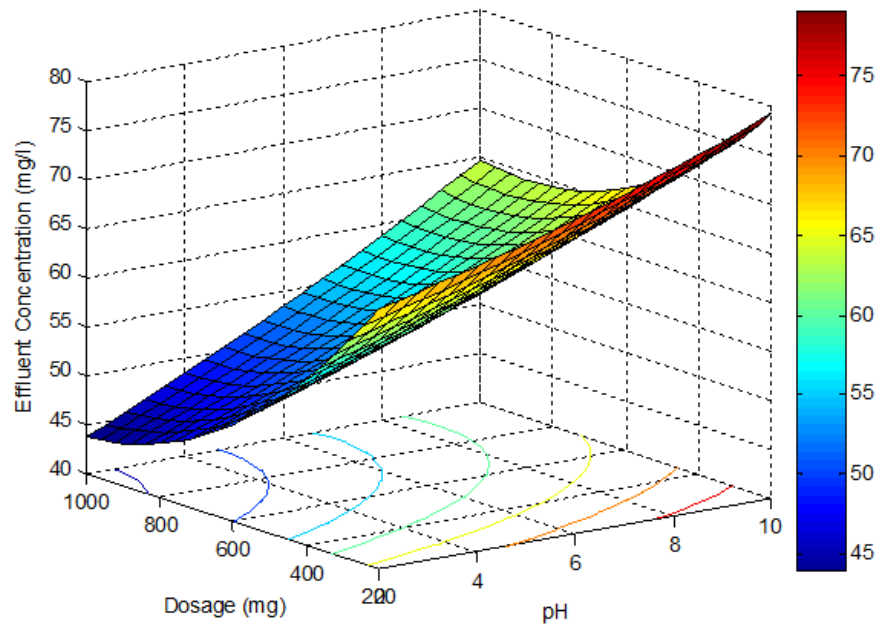

Fig. 3. 3-D Surface response Plot for PKN with $\mathrm{H}_{2} \mathrm{SO}_{4}$

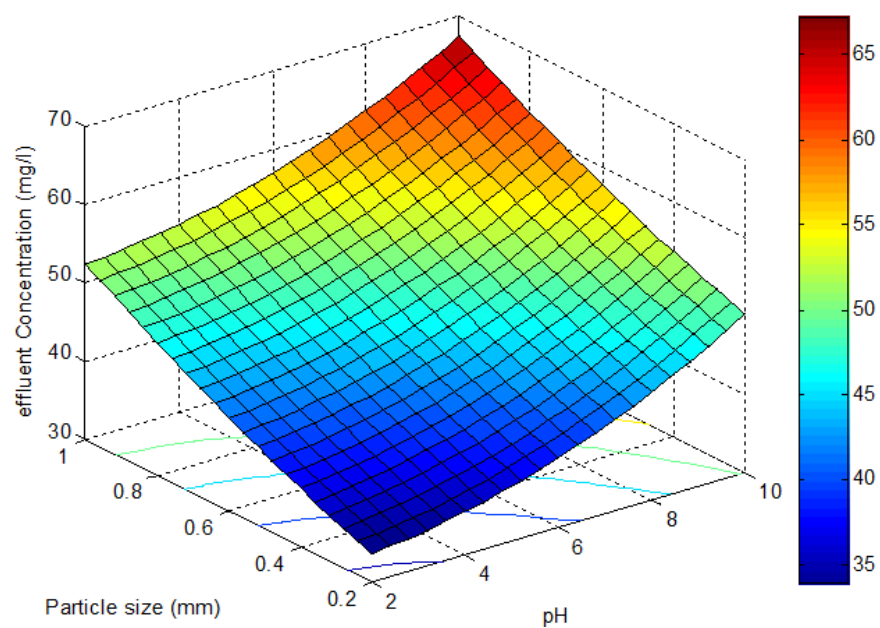

Fig. 4. 3-D Surface response Plot for PKN activated activated with $\mathrm{Al}_{2}\left(\mathrm{SO}_{4}\right)_{3}$ 


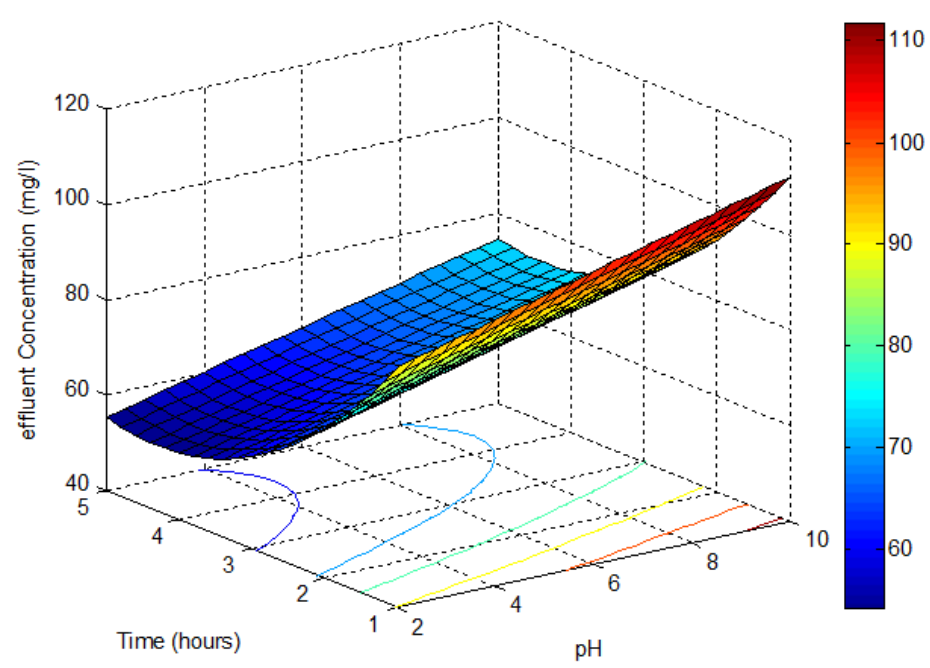

Fig. 5. 3-D Surface response Plot for $\mathrm{PKN}$ activated with $\mathrm{NH}_{4} \mathrm{Cl}$

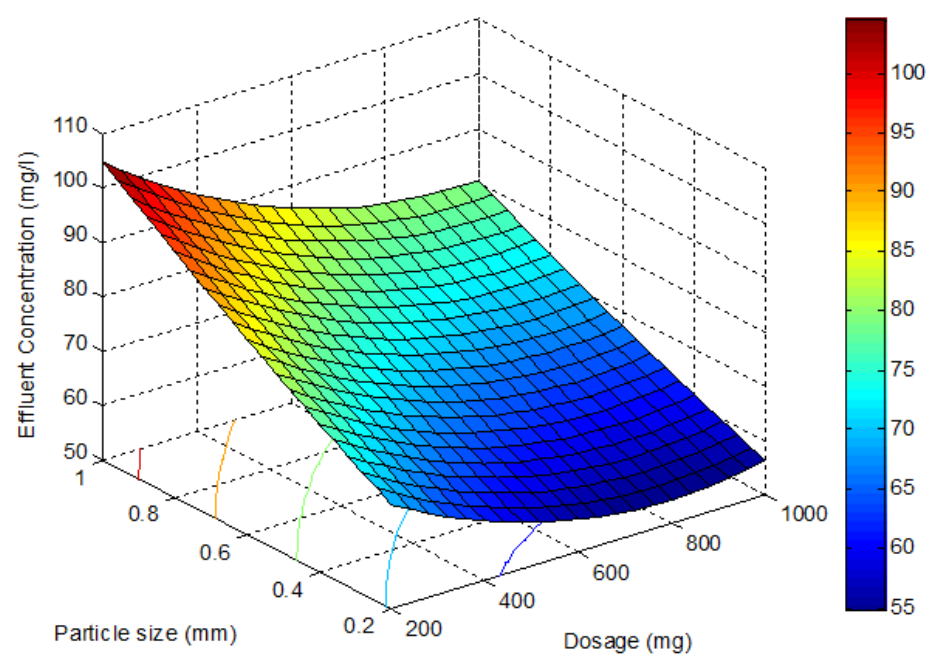

Fig. 6. 3-D Surface response Plot for $\mathrm{PKN}$ activated with $\mathrm{NH}_{4} \mathrm{Cl}$

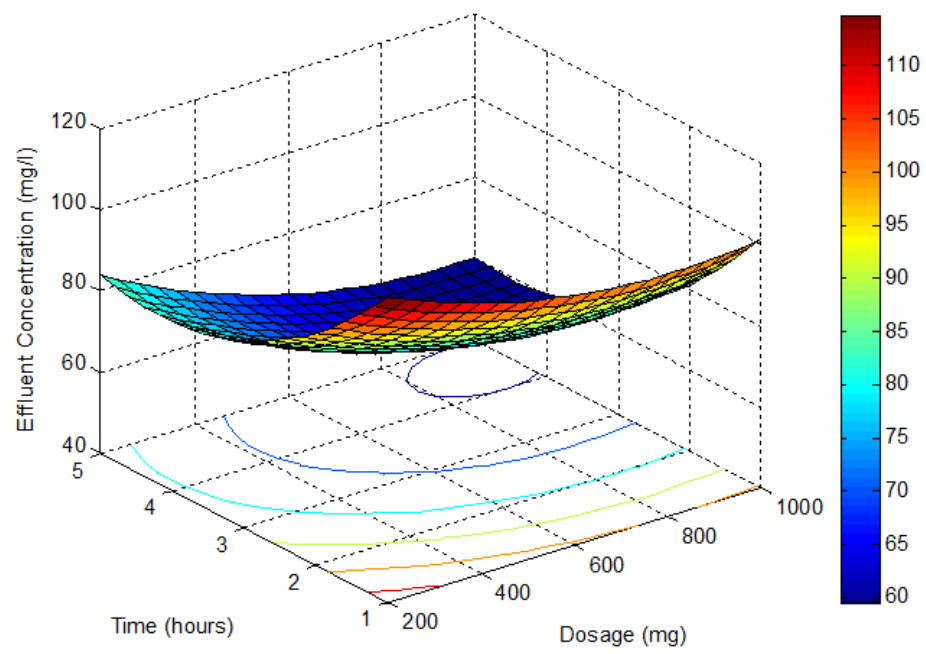

Fig. 7. 3-D Surface response Plot for $\mathrm{PKN}$ activated with $\mathrm{NH}_{4} \mathrm{Cl}$ 


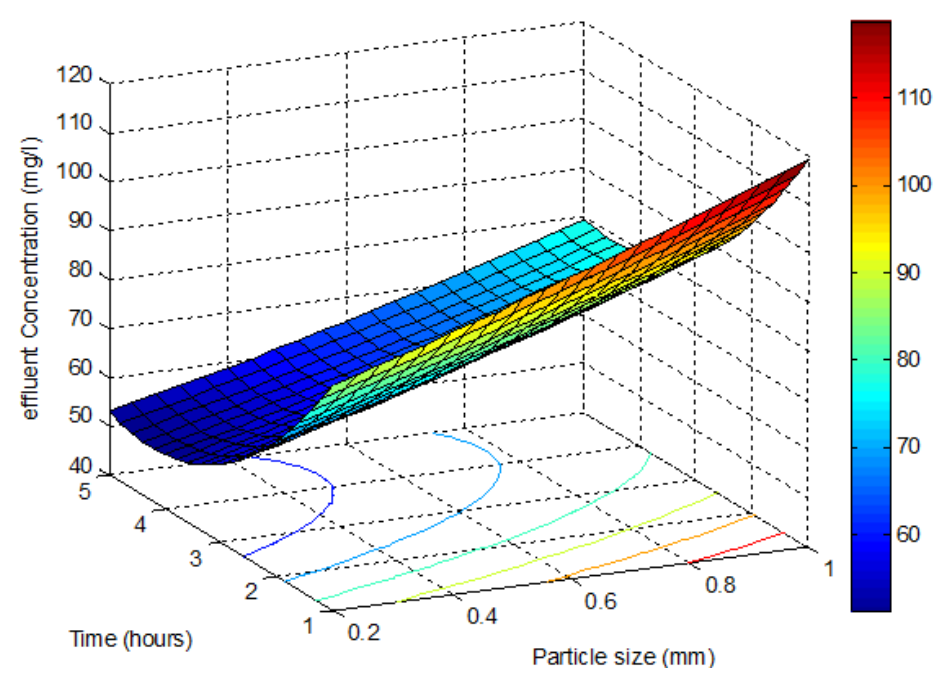

Fig. 8. 3-D Surface response Plot for $\mathrm{PKN}$ activated with $\mathrm{NH}_{4} \mathrm{Cl}$

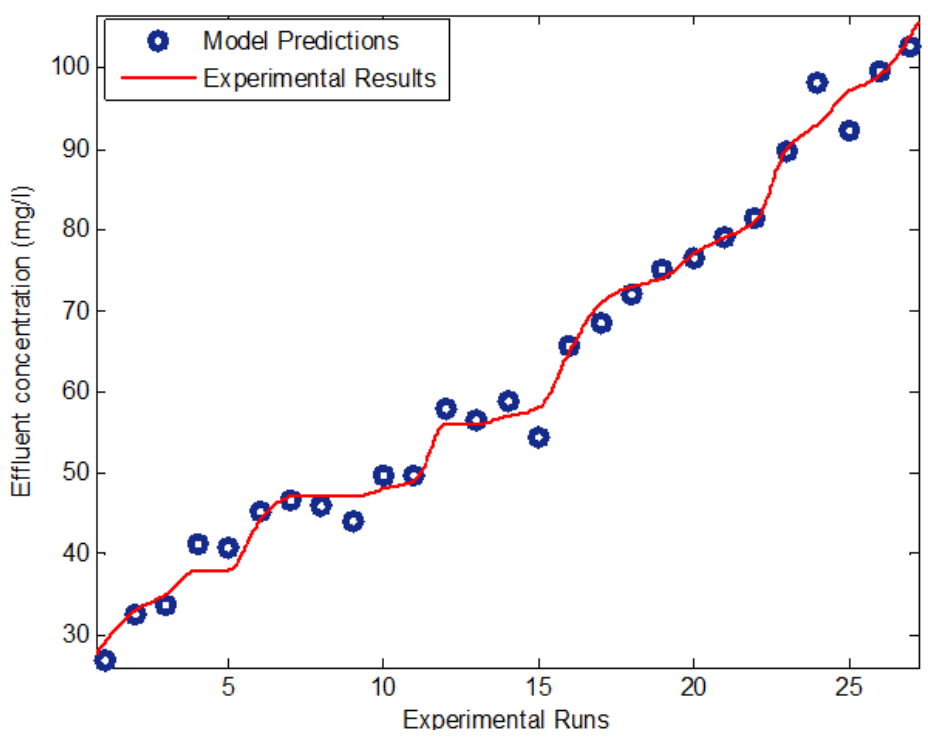

Fig. 9. Experimental Vs. Model Predictions for PKN activated with $\mathrm{H}_{2} \mathrm{SO}_{4}$

The optimization of response surface model reveals that, the minimum $\mathrm{pH} 2$, particle size $(0.2 \mathrm{~mm})$ and dosage $(1000 \mathrm{mg})$ are local while the contact time $(4.1 \mathrm{~h})$ is a global optimum. This implies that the effectiveness of the adsorbent can be improved on by operating at lower $\mathrm{pH}$, lower particle size and higher dosage than what was used in this study, but no improvement can be made by increasing the contact time beyond the stipulated optimum.

\section{Conclusion}

This research work has demonstrated that, palm kernel shell could be used as a cost effective and environmentally friendly adsorbent for the removal of phosphorus from wastewater. The adsorbent was $93.54 \%$ efficient.
The adsorption data were best described by Freundlick Isotherm. The adsorption of phosphorus on PKN was also established to be endothermic and nonspontaneous through thermodynamic studies. The optimization of response surface model also established the minimum $\mathrm{pH} 2$, particle size $(0.2 \mathrm{~mm})$ and dosage (1000 $\mathrm{mg})$ to be local while the contact time $(4.1 \mathrm{~h}) \mathrm{a}$ global optimum for the process.

\section{Acknowledgement}

The authors appreciate the Managing Director and the technical Staff, Federal Superphosphate Fertilizer Company, Kaduna for making the effluent available for this work. 


\section{Ethics}

Authors should address any ethical issues that may arise after the publication of this manuscript.

\section{References}

Akpor, O.B., C.O. Nwonuma, T.I. Edewor-Kuponiyi and O.J. Amira, 2013. The role of Ripe Musa sapientum (plantain) peels in the removal of phosphorus and nitrogen from aqueous solution. J. Biol. Agric. Health Care, 3: 85-96.

Babayemi, A.K., 2014. Removal of phosphorus from industrial and synthetic effluents using Nonconventional coag-flocculation and adsorption. Ph.D Thesis, Nnamdi Azikiwe University, Nigeria.

Babayemi, A.K., 2015. Phosphate removal from phosphorus containing waste water by coagulation/flocculation process using Gossypium spp. (GS) as coagulant. Curr. Adv. Environ. Sci., 3: 1-5. DOI: 10.14511/caes.2015.030101

Bansal, R.C. and M. Goyal, 2005. Activated Carbon Adsorption. CRC Press. 1st Edn., U.S.A, ISBN-10: 1420028812, pp: 520.

Fridriskhberg, D.A., 1984. A Course in Colloidal Chemistry. 1st Edn., Mir Publishers, Moscow, Russia.

Gueu, S., B. Yao, K Adouby and G. Ado, 2006. Heavy metals removal in aqueous solution by activated carbons prepared from coconut shell and seed shell of the palm tree. J. Applied Sci., 6: 278-293.

DOI: $10.3923 /$ jas.2006.2789.2793
Menkiti, M.C., 2010. Sequential treatment of coal washery and brewery effluents by biocoagflocculation and activated carbon adsorption. Ph.D Thesis, Nnamdi Azikiwe University Nigeria.

Metcalf and Eddy, 2003. Wastewater Engineering: Treatment and Reuse. 4th Edn., Tafa Mc Graw-Hill Publishers, New Delhi.

Nwabanne, J.T., 2010. Adsorption and kinetic modeling of heavy metals uptake from wastewater effluents. Ph.D Thesis, Nnamdi Azikiwe University, Nigeria.

Reynolds, T.D. and P.A. Richards, 1996. Unit Operations and Processes in Environmental Engineering. 2nd Edn., PWS Publishing Company, Stamford, ISBN-10: 0534948847, pp: 798.

Roque-Malherbe, R.M.A., 2007. Adsorption and Diffusion in Nanoporous Materials. 1st Edn., CRC Press, USA., ISBN-10: 1420046764, pp: 288.

Sincero, A.P. and G.A. Sincero, 2004. Environmental Engineering: A Design Approach. Prentice-Hall Publisher, India.

Surche, K.M.S., 2011. Agricultural wastes as low cost adsorbents for $\mathrm{Pb}$ removal: Kinetics, equilibrium and thermodynamics. Int. J. Chem., 3: 103-112. DOI: $10.5539 /$ ijc.v3n3p103

Uwadiae, Y., Yerima and R.U. Azike, 2010. A comparative study of sorption of heavy metal ions by granular activated carbon from coconut shell sawdust and groundnut shell. J. Sci. Multidisciplinary Res., 2: 127-134. 